\title{
Nuclear Factor of Activated T-Cells 5
}

National Cancer Institute

\section{Source}

National Cancer Institute. Nuclear Factor of Activated T-Cells 5. NCI Thesaurus. Code C93134.

Nuclear factor of activated T-cells 5 (1531 aa, $166 \mathrm{kDa}$ ) is encoded by the human NFAT 5 gene. This protein is involved in the modulation of transcription. 